удК 341.4

DOI https://doi.org/10.32837/apdp.v0i87.2796

М.І.Іліка

\title{
ЗВЕРНЕННЯ ДО ДЖЕРЕЛ НАЦІОНАЛЬНИХ ПРАВОВИХ СИСТЕМ ДЛЯ ТЛУМАЧЕННЯ ЗАГАЛЬНИХ ПРИНЦИПІВ ПРАВА У ПРАКТИЦІ ОРГАНІВ МІЖНАРОДНОЇ КРИМІНАЛЬНОЇ ЮСТИЦІЇ
}

Постановка проблеми. Значення загальних принципів права як джерела міжнародного права зростає з розвитком міжнародної юстиції, зокрема у сфері міжнародного кримінального правосуддя. Звернення до цього джерела міжнародного права дозволяє заповнити прогалини у правозастосуванні, вирішити колізії та з'ясувати зміст положень міжнародно-правових норм у міжнародному кримінальному процесі. Саме тому питання тлумачення загальних принципів права міжнародними кримінальними судами і трибуналами, зокрема через звернення до норм національного права, є актуальним напрямом міжнародно-правових досліджень.

Метою цієї статті є встановлення форм та способів, які застосовуються міжнародними кримінальними судами і трибуналами в разі звернення до національних правових систем для тлумачення загальних принципів права.

Стан дослідження проблеми. Проблематика загальних принципів права як джерела міжнародного права та їх тлумачення неодноразово була предметом досліджень українських учених. Зокрема, варто відзначити праці С.М. Задорожної, О.В. Київець, О.О. Мережка, О.О. Нігреєвої, О.М. Юхимюк та інших. Серед закордонних дослідників цієї проблеми варто назвати М.Ш. Бассіуні та Ф.О. Раймондо. Водночас проблема тлумачення загальних принципів права у сфері міжнародного кримінального правосуддя залишається недослідженою в українській міжнародно-правовій доктрині.

Діяльність органів міжнародної юстиції із тлумачення джерел міжнародного права є однією з основних сфер їхньої діяльності і не лише має практичне значення для сторін спору, а й робить внесок у теоретичні підходи до їх розуміння. Особливо важливою така правотлумачна практика є для теоретико-правового розуміння допоміжних джерел міжнародного права, зокрема і загальних принципів права, визнаних цивілізованими націями.

У контексті цього джерела міжнародного права особливо велике значення має саме практика міжнародних кримінальних судів і трибуналів. Як відзначають юристи-міжнародники, ці органи чи не найчастіше за інші органи міжнародної юстиції застосовують їх на практиці. На думку Ф.О. Раймондо, це зумовлено тим, що «нерозвиненість міжнародного кримінального права, неточність багатьох його правових норм, необхідність наводити переконливі юридичні аргументи і наявність відповідних аналогій у національному кримінальному праві сприяли застосуванню загальних принципів права у практиці міжнародних кримінальних судів і трибуналів» [1, с. 74].

(C) М. I. Іліка, 2020 
Органи міжнародної кримінальної юстиції у своїй практиці неодноразово наголошували на важливості звернення до національних правових систем у процесі тлумачення загальних принципів права під час ухвалення рішень. Наприклад, Міжнародний кримінальний трибунал для колишньої Югославії (далі - МТКЮ) у рішенні у справі «Прокурор проти Фурунджія» наголосив на необхідності звернення «до принципів кримінального права, спільних для головних правових систем світу», які можуть походити також і з «національного законодавства» [2, par. 179].

Якщо говорити про конкретні приклади такого застосування тлумачення загальних принципів права органів міжнародної кримінальної юстиції, то варто навести практику Міжнародного військового трибуналу (далі - MBT, або Нюрнберзький трибунал). Вказаний орган звертався до національного права, зокрема під час обгрунтування неможливості автоматичного звільнення від відповідальності через виконання наказів або розпоряджень.

Принцип «виконання наказів звільняє від відповідальності» застосовувався і до Другої світової війни, зокрема в Лейпцизьких військових процесах щодо злочинів, скоєних німецькими військовими під час Першої світової війни. Так, у справі щодо потоплення британського госпітального судна «Дувр Касл» капітана К. Неймана, командира підводного човна “UC-67” було виправдано, оскільки він лише виконував накази, видані командуванням Імперського німецького флоту [3, с. 499-500]. Як наголошує Дж.А. Фінч, цей судовий орган зазначав, що: «<...> усі цивілізовані нації визнають принцип, згідно з яким підлеглий підкоряється наказам свого командування» [4, с. 440-445], тому вони мають бути звільнені від відповідальності за виконання наказів.

Проте МВТ відступив від цього принципу, обмежив його застосування лише як обставину, яка може пом'якшити відповідальність, зафіксував це у ст. 8 Статуту Трибуналу. А у своїх рішеннях для обгрунтування цього підходу цей міжнародний судовий орган звернувся до практики національних судових органів і зазначив, що: «Справжня мета встановлення цього факту (виконання чи невиконання наказів - M. I.), яка тією чи іншою мірою наявна у кримінальному законодавстві більшості держав, полягає не в існуванні чіткої відповіді щодо винуватості, а у встановленні того, чи був моральний вибір насправді можливий», або ж у виявленні того, чи обвинувачений справді виконував наказ чи діяв на власний розсуд [5, с. 42].

Ще одним аспектом, на якому варто наголосити, є те, що під час обгрунтування застосування та тлумачення загальних принципів права через звернення до практики та їх застосування в національних системах права міжнародні кримінальні суди та трибунали звертаються не просто до національного законодавства, тобто конкретних внутрішньодержавних правових актів, а до національного права загалом. Тобто практика різних таких органів, зокрема МТКЮ, свідчить, що поняття «національне право», за допомогою якого може здійснюватися тлумачення, включає і норми законодавства, i правову доктрина, і судову прецедентну практику.

Зокрема, такий підхід було застосовано Судовою палатою МТКЮ в рішенні у справі «Прокурор проти Ердемовіча», де дотримано принцип, згідно з яким «умови застосування таких обставин пом'якшення відповідальності, як примус, стан крайньої необхідності та виконання наказів є особливо жорсткими» (англ.: 
"the conditions of application of the defences of duress, state of necessity, and superior orders are particularly strict”). У цьому рішенні Трибунал, звернувшись до національного права? констатував, що «загальні принципи права, що виражені в численних національних законах та судовій практиці», підтверджують, що умови їх застосування є особливо суворими [6, par. 19].

Навіть більше, поняття «національне право» у розумінні міжнародних кримінальних судів та трибуналів включає також спеціальні джерела. Наприклад, у рішенні щодо ознайомлення та перевірки свідків у справі «Ситуація в Демократичній Республіці Конго» МКС під час дослідження систем національного права для встановлення факту існування загального принципу права звертався, серед іншого, і до аналізу кодексів поведінки національних асоціацій адвокатів [7, par. 38-39].

Водночас невирішеним залишається питання стосовно якісних та кількісних критеріїв, які повинні застосовуватися в разі звернення до змісту загальних принципів права для належного їх тлумачення органами міжнародної кримінальної юстиції. Так, вищезгаданий підхід суду у справі «Прокурор проти Ердемовіча» критикувався через недостатність посилань на «національні закони та судову практику», якими Судова палата МТКЮ обгрунтовувала застосування цього принципу [1, с. 96].

3 іншого боку, як відзначає Ф.О. Раймондо, МТКЮ в рішенні у справі «Прокурор проти Кунараца та інших» встановив, що «існування загального принципу права визначається, якщо широке коло національних систем права - не всі вони визнають загальний правовий принцип, про який йдеться» $[1$, с. 135]. Тобто необхідно встановити спільність та визнаність цього принципу, а не будь-які кількісні параметри.

Частково відповідь на це питання можна знайти під час проведення аналізу практики все того ж МТКЮ, який демонструє, що органи міжнародної кримінальної юстиції не просто звертаються до національного права певної кількості держав, але й ураховують необхідність того, щоб ці держави представляли різні правові системи. Зокрема, як відзначають дослідники, у практиці можна простежити диференціацію таких правових систем на систему «цивільного права» (англ. civil $l a w)$, тобто романо-германську, нормативно-актну, або континентальну, «загального права» (англ. common law), тобто англо-саксонську, або ж прецедентну та правову систему «інших держав» [1, с. 106; 8, par. 49]. В інших рішеннях виділялася також і «марксистська» правова система [9, par. 535-539]. Щоправда, чіткого поділу окремих держав за їхньою приналежністю до тієї чи іншої правової сім’ї у практиці міжнародних кримінальних судів та трибуналів теж немає: так, Китай у різних випадках відносили і до «інших правових систем», і до «марксистської правової системи» [8, par. 60; 9, par. 535-539].

Так само немає чітких кількісних критеріїв щодо того, скільки саме національних систем права повинні бути проаналізовані, які саме це держави повинні бути. Наприклад, у рішенні МТКЮ у справі «Прокурор проти Тадіча» були проаналізовані 12 європейських національних систем права та 1 азійська [9, par. 535-539]. В окремій думці суддів Г.К. Макдональд та Л.Ч. Вохра до рішення Апеляційної 
палати Трибуналу у справі «Прокурор проти Ердемовіча» було розглянуто приклади із 30 національних систем права (13 європейських, 6 латиноамериканських, 5 африканських, 4 азійських та 2 північноамериканських) [8]. У рішенні у справі «Прокурор проти Кунараца та інших» було проаналізовано національне кримінальне право 33 держав (15 європейських, 6 азійських, 5 латиноамериканських, 3 африканських, 2 північноамериканських, 2 океанічних) [10, par. 453-456].

Такі ж підходи щодо широкого компаративного звернення до національного права різних держав під час тлумачення загальних принципів права застосовуються й у практиці Міжнародного кримінального суду (далі - МКС). Наприклад, у рішенні у справі «Ситуація в Демократичній Республіці Конго» щодо запиту на надзвичайний розгляд. У цій справі сторона обвинувачення обгрунтовувала в запиті своє тлумачення загальних принципів права через посилання на 22 національні системи права, які були розділені за правовими системами (14 - з романо-германської правової сім'ї, 5 - з англосаксонської, 3 - з ісламської) [11, par. 26-31].

Варто зазначити, що органи міжнародного кримінального правосуддя піддаються критиці не так за кількісні параметри, як за нерепрезентативність такого порівняльного аналізу. Так, Апеляційна палата МТКЮ в рішенні у справі «Прокурор проти Делаліча та інших" намагалася витлумачити, чи є недоумство (англ. diminished mental responsibility) обставиною, яка звільняє від відповідальності відповідно до загальних принципів права. Для встановлення цього факту Трибунал проаналізував національне кримінальне право 16 держав (10 європейських, 3 азійських, 1 океанської, 1 африканської, 1 північноамериканської) [12, par. 585-588].

У своїх працях Ф.О. Раймондо зазначає, хоча така кількість і є «значною», вона водночас є й обмеженою в якісному плані, оскільки включає лише одну африканську систему права і жодної латиноамериканської. Він слушно відзначає, що така географічна диверсифікація цього переліку «не обов’язково змінила б результат дослідження, але зробило б його справді міжнародним і, таким чином, більш співзвучним по суті універсальному характеру загальних принципів права як джерела міжнародного права» [1, с. 132-133].

Аналогічно цей учений критикував підхід, застосований МКС у рішенні у справі «Ситуація в Демократичній Республіці Конго», коли Суд під час тлумачення у зв'язку із встановленням існування та можливістю застосування загального принципу права, який передбачає безумовну можливість апеляційного оскарження будь-яких рішень судів нижчої інстанції в судах вищої інстанції, проаналізував національне право 14 держав, серед яких не було жодної африканської [1, с. 155].

Іншими критеріями, які можна було виділити у практиці МТКЮ щодо цього підходу поруч із необхідністю забезпечення репрезентативності, є:

- «практична доступність» матеріалів національного права (законодавство, наукова доктрина, судова практика) цих держав [8, par. 57];

- аналіз відповідного національного права, яке було чинним на час подій, які стосуються провадження [10, par. 42].

Необхіднозазначити, щоджереланаціональногоправачасто розглядаються органами міжнародної кримінальної юстиції лише як субсидіарне джерело для тлума- 
чення загальних принципів права, визнаних цивілізованими націями. Наприклад, у тій же справі «Прокурор проти Ердемовіча» МТКЮ для тлумачення та доведення факту існування такого загального принципу права, як «найсуворіші покарання застосовуються до злочинів проти людяності" (англ.: “the severest penalties apply to crimes against humanity”), звернувся до національної судової практики колишньої Соціалістичної Федеративної Республіки Югославія (далі - СФРЮ).

У результаті проведеного аналізу цієї практики МТКЮ дійшов висновку, що «усі обвинувачені, які вчинили свої злочини на території колишньої Югославії, могли очікувати кримінальної відповідальності» та не могли не знати про злочинний характер своїх діянь [6, par. 40]. Це означає, що винні у вчиненні цих злочинів на момент їх учинення усвідомлювали, що можуть понести якнайсуворіше покарання. Трибунал підтвердив цей факт і обгрунтував існування та допустимість застосування цього загального принципу права та водночас підкреслив, що не зв'язаний рішеннями югославських судів під час подальшого ухвалення власних рішень із застосуванням згаданого принципу, зазначив, що відповідна практика буде переглянута, однак він «жодним чином не буде пов'язувати цю практику у встановлених ним покараннях та вироках, які будуть винесені за злочини, що підпадають під його юрисдикцію» [6, par. 40], тобто злочини проти людяності, воєнні злочини та геноцид.

На нашу думку, підхід, коли міжнародні кримінальні суди і трибунали тлумачать загальні принципи права відповідно до обставин справи та зважають на загальний контекст справи, а не лише враховують відповідну національну прецедентну практику, є обгрунтованим. Однак допустимі теоретично і практично ситуації, коли саме підходи, зумовлені національними законодавствами, доктринами та судовою практикою, будуть оптимальними для ухвалення рішень такими органами, їх ігнорування чи відступ від них будуть неправильними.

Навіть більше, у практиці міжнародних кримінальних судів та трибуналів трапляється, коли факт існування та допустимості застосування загальних принципів права здійснюється лише в разі підтвердження їх існування в національних правових системах. Зокрема, такий підхід спостерігався у вироку у справі «Прокурор проти Тадіча» стосовно дотримання загального принципу права «один свідок - це не свідок» [9, par. 535-539].

Такий же підхід було застосовано і у практиці Міжнародного кримінального трибуналу для Руанди (далі - МТР). Так, у рішенні у справі «Прокурор проти Акаєсу" Трибунал в обгрунтування застосування “favor rei", у частині вибору між французькою й англійською термінологією для визначення злочину вбивства (“meurtre” або “killing”) визначив, що згідно із цим принципом перевага повинна бути віддана саме французькій версіі, аргументував це тим, що руандійське законодавство містить цей термін саме в такій редакції [13, par. 500-501].

Якщо говорити про оцінки такого підходу до тлумачення загальних принципів права в доктрині міжнародного кримінального права, то інколи можна його критикують як однобоке. Наприклад, Н. Джейн у результаті проведеного аналізу практики МТКЮ твердить, що порівняльний метод пошуку та підтвердження загальних принципів права в національному праві застосовується органами між- 
народного кримінального правосуддя здебільшого як негативний, тобто для заперечення можливості застосування цих принципів у своїй практиці [14, с. 489].

Такий «негативний» підхід щодо звернення до національного права для тлумачення загальних принципів права справді має місце, зокрема, ми його розглядали вище щодо рішень у справі МТКЮ «Прокурор проти Тадіча» [9, par. 535-539], коли було заперечено можливість застосування принципу «один свідок - це не свідок» та в рішенні МВТ щодо застосування принципу «виконання наказів звільняє від відповідальності» [5, с. 42]. Проте ми не підтримуємо позицію Н. Джейн стосовно того, що метою звернення до джерел національного права було саме заперечення існування та допустимості застосування окремих загальних принципів права.

На нашу думку, цей підхід не має наперед визначеного наміру довести або спростувати існування чи допустимість застосування загальних принципів або ж довести зворотні факти. Міжнародні кримінальні суди та трибунали звертаються до національного права саме з тим, щоб встановити зміст тих чи інших загальних принципів і вже тоді робити висновки щодо них. Зокрема, такий останній, «позитивний» підхід мав місце в рішенні МТКЮ у справі «Прокурор проти Ердемовіча» щодо принципів «найсуворіші покарання застосовуються до злочинів проти людяності» [6, par. 40] та «умови застосування таких обставин пом'якшення відповідальності, як примус, стан крайньої необхідності та виконання наказів, є особливо суворими» [6, par. 19].

Отже, визнаною та поширеною є практика, коли міжнародні кримінальні суди і трибунали, у процесі застосування та тлумачення загальних принципів права звертаються до національних правових систем. Метою звернення є доведення факту їхнього існування, допустимості або недопустимості їх застосування у практиці міжнародного кримінального права та може розглядатися як умова такого застосування у принципі. Варто наголосити, що зазначене тлумачення здійснюється органами міжнародної кримінальної юстиції з використанням компартивістських підходів та врахуванням принципів диференціації за правовими системами і географічним принципом. Цей метод тлумачення підкреслює універсальне значення як загальних принципів права, так і міжнародного кримінального права, встановлює зв'язок між національним та міжнародним кримінальним правом.

\section{Jimepamypa}

1. Raimondo F.O. General principles of law in the decisions of international criminal courts and tribunals. Leiden ; Boston : M. Nijhoff Pub., 2008. 214 p.

2. Prosecutor v. Furund ija, Judgment, Case № IT-95-17/1-T, T. Ch. II, 10 December 1998.

3. Solis G.D. Obedience of Orders and the Law of War: Judicial Application in American Forums. American University International Law Review. 1999. Vol. 15. Iss. 2. P. 481-526.

4. Finch G.A. Superior Orders and War Crimes. The American Journal of International Law. 1921. Vol. 15. № 3. P. 440-445.

5. Judgment of the International Military Tribunal for the Trial of German Major War Criminals (With the dissenting opinion of the Soviet Member), Nuremberg, $30^{\text {th }}$ September and $1^{\text {st }}$ October, 1946. London : HMSO, 1946. $149 \mathrm{p}$.

6. Prosecutor v. Erdemović, Sentencing Judgment, Case № IT-96-22-T, T. Ch. I, 29 November 1996.

7. Situation in the Democratic Republic of the Congo in the Case of the Prosecutor v. Thomas Lubanga Dyilo, Decision on the Practices of Witnesses Familiarization and Witness Proofing, Case № ICC-01/04-01/06, PT. Ch. I, 8 November 2006. 
8. Prosecutor v. Erdemović, Judgment, Joint Separate Opinion of Judge McDonald and Judge Vohrah, Case № IT-96-22-A, App. Ch., 7 October 1997.

9. Prosecutor v. Tadić, Opinion and Judgment, Case № IT-94-1-T, T. Ch. II, 7 May 1997.

10. Prosecutor v. Kunarac et al., Judgment, Case № IT-96-23-T \& IT-96-23/1-T, T. Ch. II, 22 February 2001.

11. Situation in the Democratic Republic of the Congo, Judgment on the Prosecutor's Application for Extraordinary Review of Pre-Trial Chamber I's 31 March 2006 Decision Denying Leave to Appeal, Case № ICC-01/04, App. Ch., 13 July 2006.

12. Prosecutor v. Delali et al., Judgment, Case № IT-96-21-A, App. Ch., 20 February 2001.

13. Prosecutor v. Akayesu, Judgment, Case № ICTR-96-4-T, T. Ch. I, 2 September 1998, § 500-501.

14. Jain N. Comparative International Law at the ICTY: The General Principles Experiment. American Journal of International Law. July 2015. Vol. 109, Iss. 3. P. 486-497.

\section{Анотація}

Іліка М. I. Звернення до джерел національних правових систем для тлумачення загальних принципів права у практиці органів міжнародної кримінальної юстиції. - Стаття.

Загальні принципи права, визнані цивілізованими націями, є одним з основних джерел міжнародної кримінальної юстиції. Їх застосування забезпечуе гнучкість та прозорості діяльності міжнародних кримінальних судів та трибуналів, дозволяє їм ефективно реагувати на виклики, які з'являються під час ухвалення рішень.

Водночас у процесі застосування загальних принципів права дуже часто постає проблема їх тлумачення. Ефективним шляхом здійснення тлумачення $є$ звернення із цією метою до національних правових систем. Такий шлях виглядає і найбільш логічним, оскільки більшість загальних принципів права з'явилися саме в національному правовому контексті, їх застосування на міжнародному рівні нерозривно пов'язане із правильним розумінням їхнього первинного значення.

У статті розглядаються приклади зі звернення міжнародних кримінальних судів та трибуналів до національних правових систем для тлумачення загальних принципів права. Зазначається, що з метою тлумачення використовується широке коло джерел: національне законодавство, судова практика, доктрина національного права тощо. Наголошується, що в такому зверненні дуже важливе забезпечення географічної різноманітності та представництва різних правових систем.

Робиться висновок, що тлумачення загальних принципів права через звернення до національних правових систем $\epsilon$ широко застосовуваною практикою у сфері міжнародної кримінальної юстиції. Міжнародні кримінальні суди і трибунали звертаються як у цілях підтвердження існування та застосування загальних принципів, так і з метою встановлення їхнього змісту.

У статті наголошується, що важливою умовою здійснення такого тлумачення є дотримання компаративістських підходів, що є гарантією їхнього універсального характеру як джерела права. Застосування такого тлумачення є свідченням того, що загальні принципи права є загальновизнаними джерелами кримінального та міжнародного кримінального права, слугують зв'язковою ланкою між ними.

Ключові слова: загальні принципи права, правотлумачення, МВТ, МТКЮ, МТР.

\section{Summary}

Ilika M. I. Recourse to national legal systems for interpretation of general principles of law in the practice of international criminal justice. - Article.

The general principles of law recognized by civilized nations are one of the main sources of international criminal justice. Their application ensures the flexibility and transparency of international criminal courts and tribunals, which allows them to respond to challenges that arise in the process of a decision-making.

At the same time, in the process of their application, the problem of their interpretation often arises. An effective way for the interpretation is to refer to national legal systems. This is the most logical way, because most of the general principles of law were created in the national legal context and their application at the international level is inextricably linked with a correct understanding of their primary meaning.

The articles examine examples of the establishment of international criminal courts and tribunals in national legal systems to interpret general principles of law. It is determined that in the process of interpreting is used a wide range of sources: national legislation, case law, doctrine of national law, etc. It is emphasized that within such an application it is very important to ensure the geographical diversity and representation of different legal systems. 
It can be concluded that the interpretation of general principles of law through recourse to national legal systems is a widely used practice in the field of international criminal justice. International criminal courts and tribunals apply this way both to confirm the existence and application of general principles and to establish their content.

Articles suggests that a condition for such an interpretation is comparative approach, that guarantees their universal character of a general principles as sources of law. The application of such an interpretation indicates that the general principles of law are generally accepted as sources of criminal and international criminal law and officials, in a way, with a corresponding link between them.

Key words: general principles of law, legal interpretation, IMT, ICTY, ICTR. 